\title{
GIÁ TRI LÂM SÀNG CỦA CYSTATIN C HUYẾT THANH TRONG DƯ ĐOÁN MỨC LỌC CẦU THẬN Ở BỆNH NHÂN ĐÁI THÁO ĐƯờnG TÍP 2
}

Đụ̆ng Anh Đào ${ }^{1}$, Trần Hũú Dàng ${ }^{2}$, Trần Thù̀a Nguyên ${ }^{3}$

1. Bệnh viện Đà Nã̃ng

2. Truờng Đại học Y Dượ Huế

3. Bệnh viện TW Huế

DOI: $10.47122 / v j d e .2020 .41 .12$

\section{ABSTRACT \\ Clinical valueof serum cystatin $C$ inpredicting glomerular filtration rate in type 2 diabetic patients}

Objective: Investigated serum Cystatin C level and its clinical valuein predicting the glomerular filtration rate (GFR) in type 2 diabetic patients. Materials and methods: We studied on 115 healthy subjects with normal level of glucose and normal renal function, and 137 type 2 diabetic patients. We excluded the patients with thyroid dysfunction or taking glucocorticoid that affect the serum Cystatin level. The serum Cystatin $\mathrm{C}$ level measured in both groups. In type 2 diabetic patients, we measured renal radiography, and estimated GFR by CKD.EPI formular. Diagnostic criteria of diabetes by ADA 2015. The diagnosis of CKD and decreased GFR by KDIGO 2012. Descriptive and cross-sectional study. Statistical analyses of data were performed on SPSS. Receiver operating characteristics (ROC) analysis, calculated the area under the curve (AUC) for serum Cystatin C.Binary logistic analysis of Cystatin C with risk factors for decreasing GFR. Results: -The level of serum Cystatin C in type 2 diabetic patients was significantly higher than control group $(1,37 \pm 0,87$; 0,84 $\pm 0,09 \mathrm{mg} / \mathrm{L}, \mathrm{p}<0.001$, respectively). The positively correlation was observed between eGFR according to CKD.EPI equation based on serum Cystatin $\mathrm{C}$ and renal radiography $(\mathrm{r}=0,818 ; \quad \mathrm{p}<0.001)$. The positively correlation between eGFR according to CKD.EPI equation based on serum Creatinine-Cystatin $\mathrm{C}$ and renal radiography $(r=0,820 ; p<0.001)$. - Cystatin $C$ has a high sensitivity, specificity and ROC in the prediction of decreased GFR <
$60 \mathrm{ml} / \mathrm{min} / 1,73 \mathrm{~m}^{2}$ according to radiorenogram (93.94\%; 87.5\%; ROC 0.936; p <0.001). - The increase of Cystatin C concentration is a independent risk factor for the prediction of decreasing GFR $<60 \mathrm{ml} /$ $\min / 1.73 \mathrm{~m} 2$. Binary logistic regression model: Logistic $\left(G F R<60 \mathrm{ml} / \mathrm{min} / 1,73 \mathrm{~m}^{2}\right)=$ $-7,968+3,841 x$ serum cystatin $C$. Conclusions: The serum Cystatin $\mathrm{C}$ level in type 2 diabetic patients was significantly higher than control group. There was possitivity correlation between eGFR based on Cystatin $\mathrm{C}$ and renal radiography. Serum cystatin $C$ is superior to serum creatinine for prediction of decreased GFR. Serum Cystatin $C$ is an indepent risk factor for predicting GFR.

Key words: diabetes, glomerular filtration rate, Cystatin $C$.

\section{TÓM TẮT}

Muc tiêu: Khảo sát nồng độ và giá trị lâm sàng của Cystatin $\mathrm{C}$ huyết thanh trong dự đoán mức lọc cầu thận ở bệnh nhân ĐTĐ típ 2. Đối tự̛ng và phương pháp nghiên cứu: Nghiên cứu được thực hiện trên nhóm chứng gồm 115 đối tượng có glucose máu và mức lọc cầu thận bình thường; 137 bệnh nhân đái tháo đường típ 2. Không có tình trạng ảnh hưởng đến nồng độ Cystatin $\mathrm{C}$ huyết thanh ở cả 2 nhóm (rối loạn chức năng tuyến giáp, điều trị corticoid). Chẩn đoán ĐTĐ theo ADA 2015, giảm GFR theo KDIGO 2012. - Xét nghiệm Cystatin $\mathrm{C}$ huyết thanh thực hiện trên 2 nhóm. Đo xạ hình thận, ước đoán mức lọc cầu thận (GFR) bằng công thức CKD.EPI trên bệnh nhân ĐTĐ típ 2. Nghiên cứu được thực hiện theo phương pháp mô tả, cắt ngang. Phân tích các mối tương quan, hồi quy, tính diện tích dưới đường cong ROC cho nồng độ 
Cystatin $\mathrm{C}$ huyết thanh bằng SPSS. Kết quả: Nồng độ Cystatin $\mathrm{C}$ huyết thanh ở bệnh nhân ĐTĐT2 là $1,37 \pm 0,87 \mathrm{mg} / \mathrm{L}$ cao hơn nhóm chứng $0,84 \pm 0,09 \mathrm{mg} / \mathrm{L}(\mathrm{p}<0,001)$. -Có mối tương quan thuận giữa GFR ước tính theo công thức $\mathrm{CKD}$.EPI dựa vào Cystatin $\mathrm{C}$ huyết thanh với xạ hình thận, $\mathrm{r}=0,818 ; \mathrm{p}<0,001$. Có mối tương quan thuận giữa GFR ước tính theo công thức CKD.EPI dựa vào CreatinineCystatin $\mathrm{C}$ với xạ hình thận, $\mathrm{r}=0,820 ; \mathrm{p}<$ 0,001. - Cystatin $\mathrm{C}$ có độ nhạy, độ đặc hiệu, ROC rất cao trong dự đoángiảm GFR < $60 \mathrm{ml} /$ phút $/ 1,73 \mathrm{~m}^{2}$ theo xạ hình thận $(93,94 \%$; 87,5\%; ROC 0,936; $\mathrm{p}<0,001)$. - Tăng nồng độ Cystatin $\mathrm{C}$ là $\mathrm{YTNC}$ độc lập dự đoán giảm GFR < $60 \mathrm{ml} /$ phút $/ 1,73 \mathrm{~m}^{2}$. Mô hình hồi quy binary logistic: Logistic $($ GFR $<60$ $\left.\mathrm{ml} / \mathrm{phút} / 1,73 \mathrm{~m}^{2}\right)=-7,968+3,841 \times$ Cystatin C huyết thanh. Kết luận: Nồng độ Cystatin $\mathrm{C}$ huyết thanh ở bệnh nhân ĐTĐT2 cao hơn nhóm chứng. Có mối tương quan thuận giữa GFR ước tính dựa vào Cystatin $\mathrm{C}$ với xạ hình thận. Cystatin $\mathrm{C}$ có độ nhạy, độ đặc hiệu cao hơn creatinine trong chẩn đoán giảm GFR.Cystatin $\mathrm{C}$ là YTNC độc lập dự đoán giảm GFR $<60 \mathrm{ml} /$ phút $/ 1,73 \mathrm{~m}^{2}$.

Tù khóa: đái tháo đường, mức lọc cầu thận, Cystatin C.

Chịu trách nhiệm chính: Đặng Anh Đào

Ngày nhận bài: 4/8/2020

Ngày phản biện khoa học: 10/9/2020

Ngày duyệt bài: 11/10/2020

Email: dr.anhdao@yahoo.com

Điện thoại: 0935938668

\section{1. ĐĀT VẤN ĐỀ}

Đái tháo đường ngày càng có khuynh hướng gia tăng trên toàn cầu. Theo IDF 2017, toàn thế giới có khoảng 425 triệu người trưởng thành mắc đái tháo đường (ĐTĐ), chiếm $8,8 \%$ dân số [8].

Bệnh thận đái tháo đường là biến chứng thường gặp ở bệnh nhân đái tháo đường với tỷ lệ $20-40 \%$, là nguyên nhân hàng đầu dẫn đến suy thận mạn giai đoạn cuối ở các nước phát triển.

Rối loạn chức năng thận ở bệnh nhân đái tháo đường có thể do tình trạng tăng tiết bài tiết albumin niệu hoặc giảm mức lọc cầu thận (GFR) < $60 \mathrm{ml} /$ phút $/ 1,73 \mathrm{~m}^{2}$ [9], [14].

Đánh giá lâm sàng chức năng thận là một trong những công việc thường quy và quan trọng trong y khoa. GFR được chấp nhận rộng rãi như là một chỉ số tốt nhất cho chức năng thận ở người bình thường cũng như người bệnh. Giá trị chính xác của GFR là cần thiết để đưa ra một quyết định tối ưu trong nhiều bối cảnh lâm sàng. Dựa vào GFR để chẩn đoán và phân độ giai đoạn bệnh thận mạn, tính toán độ thanh thải các thuốc... [10], [11].

Hướng dẫn của KDIGO 2012 về đánh giá và quản lý bệnh thận mạn $(\mathrm{CKD})$ khuyến cáo các bác sĩ lâm sàng sử dụng creatinine như là xét nghiệm ban đầu để ước tính MLCT. Ước tính GFR bằng Cystatin $\mathrm{C}$ hay đo lường GFR (xạ hình thận) là xét nghiệm cần thiết để đánh giá lại GFR nhằm đưa ra một quyết định lâm sàng đúng đắn [9].

Gần đây đã có nhiều nghiên cứu đã chứng minh rằng Cystatin $\mathrm{C}$ huyết thanh nổi lên như là một chỉ điểm sinh học có thể ứng dụng trong lâm sàng để đánh giá các rối loạn chức năng thận chính xác và sớm hơn các dấu ấn sinh học truyền thống trước đây như Creatinine máu [12], [18].

Vì vậy mục tiêu nghiên cứu của đề tài:

- Đánh giá nồng độ Cystatin C huyết thanh ở bệnh nhân ĐTÐ típ 2.

- Khảo sát giá trị lâm sàng của Cystatin $C$ huyết thanh trong dụ đoán múc lọc cầu thận ở bệnh nhân ĐTĐ típ 2.

\section{2. ĐỐI TƯợNG VÀ PHƯƠNG PHÁP NGHIÊN CÚU}

\section{1. Đối tượng nghiên cứu}

Tiêu chuẩn chọn bệnh:

$>$ Nhóm chứng bao gồm 115 đối tượng có glucose máu và GFR bình thường. đối tượng.

Tiêu chuẩn loại trù̀ cho 2 nhóm:

> Hiện không mắc các bệnh lý cấp tính và các tình trạng ảnh hưởng đến nồng độ Cystatin $\mathrm{C}$ huyết thanh như: cường giáp, suy giáp, đang điều trị corticoide. 
> Không có tổn thương thận thực thể trên siêu âm như: $u$ thận, đa nang thận, sỏi thận hoặc tắc nghẽn đường tiết niệu.

\subsection{Phương pháp nghiên cứu}

Thiết kế nghiên cứu: Nghiên cứu được thực hiện theo phương pháp mô tả, cắt ngang.

Các bước tiến hành:

- Các thông số cần thu thập:

- Xét nghiệm Cystatin C huyết thanh (HT) ở nhóm chứng và nhóm bệnh trên trên hệ thống máy Cobas 501/Cobas 6000 của Roche bằng phương pháp miễn dịch đo độ đục.

- Xét nghiệm Creatinine HT và các xét nghiệm khác liên quan đến nghiên cứu trên bệnh nhân ĐTĐ típ 2.

- Xạ hình thận trên nhóm bệnh nhân ĐTĐ típ 2 với chất Tc-99m-DTPA

- Các tiêu chuẩn chẩn đoán:

- Chẩn đoán glucose máu bình thường theo ADA 2015 khi thỏa mãn các tiêu chuẩn[2], [6]:

- Glucose huyết tương đói $<100 \mathrm{mg} / \mathrm{dl}$ $(5,6 \mathrm{mmol} / \mathrm{l})$, và

- HbA1c $<5,7 \%$, và
- Nghiệm pháp dung nạp glucose $($ OGTT) $<140 \mathrm{mg} / \mathrm{dl}(7,8 \mathrm{mmol} / \mathrm{l})$

- Chẩn đoán ĐTĐ theo ADA 2015 khi có một trong các tiêu chuẩn sau[2], [6]:

- Glucose huyết tương đói $\geq 126 \mathrm{mg} / \mathrm{dl}$ (7mmol/1), hoặc HbA1c $\geq 6,5 \%$, hoặc

- Nghiệm pháp dung nạp glucose $($ OGTT) $\geq 200$ mg/dl (11,1 mmol/l), hoặc

- Glucose huyết tương bất kỳ $\geq 200$ $\mathrm{mg} / \mathrm{dl}$ và triệu chứng cổ điển của ĐTĐ

- Tính GFR ước tính dựa vào Creatinine, Cystatin $\mathrm{C}$ đơn độc hoặc phối hợp được bằng các công thức CKD.EPI. theo KDIGO 2012 [9]

- Mức lọc cầu thận bình thường GFR $\geq 90$ $\mathrm{mL} /$ phút $/ 1,73 \mathrm{~m}^{2}$ [9]

- Giảm mức lọc cầu thận khi GFR $<60$ $\mathrm{mL} /$ phút/1.73 $\mathrm{m}^{2}$ [9]

2.3. Xử lý số liệu: Bằng phần mềm thống kê SPSS phiên bản 22.0.

Tính tương quan giữa các công thức GFR theo Creatinine, Cystatin $C$ với xạ hình thận; tính đường cong ROC, độ nhạy, độ đặc hiệu của Cystatin $\mathrm{C}$ trong chẩn đoán giảm GRF, phân tích hồi quy binary logistic.

\section{KẾT QUẢ NGHIÊN CỨU}

\subsection{Một số đặc điểm chung của nhóm nghiên cứu}

Bảng 3.1. Một số đặc điểm chung của các nhóm nghiên cứu

\begin{tabular}{|c|c|c|c|c|}
\hline Thông số & Nhóm nghiên cứu & $\begin{array}{l}\text { Nhóm chứng } \\
(\mathbf{n}=115)\end{array}$ & $\begin{array}{c}\text { Nhóm ĐTÐT2 } \\
\quad(\mathbf{n}=137)\end{array}$ & $\mathbf{p}$ \\
\hline Độ tuổi (1 & & $54,72 \pm 10,95$ & $57,17 \pm 8,84$ & $>0,05$ \\
\hline Giới tính & $\operatorname{Nam}(\mathrm{n} ; \%)$ & $51(44,35 \%)$ & $72(52,55 \%)$ & $>005$ \\
\hline$(\mathrm{n}, \%)$ & Nữ $(n ; \%)$ & $64(55,65 \%)$ & $65(47,45 \%)$ & 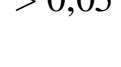 \\
\hline Thời gian & hiện bệnh ĐTĐ (năm) & - & $6,27 \pm 5,69$ & - \\
\hline BMI $(\mathrm{kg} /$ & & $22,25 \pm 1,19$ & $23,44 \pm 3,45$ & $<0,05$ \\
\hline Vòng bụn & & $80,54 \pm 4,96$ & $88,51 \pm 7,49$ & $<0,05$ \\
\hline HATT (m & & $119,64 \pm 13,72$ & $129,91 \pm 18,84$ & $<0,05$ \\
\hline HATTr $(\mathrm{n}$ & & $74,00 \pm 7,47$ & $78,47 \pm 8,82$ & $<0,05$ \\
\hline Tăng huy & Không & $98(85,22 \%)$ & $87(63,50 \%)$ & - \\
\hline
\end{tabular}




\begin{tabular}{|l|l|c|c|c|}
\hline \multicolumn{1}{|c|}{ Có $\%)$} & $17(14,78 \%)$ & $50(36,50 \%)$ & $<0,05$ \\
\hline Glucose HT (mmol/l) & $4,80 \pm 0,52$ & $10,14 \pm 6,31$ & $<0,05$ \\
\hline HbA1c (\%) & $5,20 \pm 0,25$ & $8,53 \pm 2,41$ & $<0,05$ \\
\hline
\end{tabular}

3.2. Nồng độ Cystatin $\mathrm{C}$ huyết thanh và mức lọc cầu thận ở các nhóm nghiên cứu

Bảng 3.2. Nồng độ Cystatin $\mathrm{C}$ huyết thanh ở các nhóm nghiên cứu

\begin{tabular}{|c|c|c|c|c|}
\hline $\begin{array}{l}\text { Các chỉ điể } \\
\text { sinh học }\end{array}$ & Nhóm nghiên cứu & $\begin{array}{l}\text { Nhóm chứng } \\
\text { (n=115) }\end{array}$ & $\begin{array}{c}\text { Nhóm ĐTÐT2 } \\
\quad(\mathbf{n}=137)\end{array}$ & $\mathbf{p}$ \\
\hline Cystatin C & $\bar{X} \pm S D$ & $0,84 \pm 0,09$ & $1,36 \pm 0,87$ & \\
\hline$(\mathrm{mg} / \mathrm{L})$ & $\begin{array}{l}\text { Trung vị } \\
\text { (khoảng tứ phân vị) }\end{array}$ & $\begin{array}{c}0,85 \\
(0,79-0,91) \\
\end{array}$ & $\begin{array}{c}1,01 \\
(0,88-1,44) \\
\end{array}$ & $<0,001$ \\
\hline Creatinine & $\bar{X} \pm S D$ & $62,44 \pm 10,81$ & $112,12 \pm 109,69$ & \\
\hline$(\mu \mathrm{mol} / \mathrm{l})$ & $\begin{array}{l}\text { Trung vị } \\
\text { (khoảng tứ phân vị) }\end{array}$ & $\begin{array}{c}60 \\
(55-70)\end{array}$ & $\begin{array}{c}77 \\
(58-111,5)\end{array}$ & $<0,001$ \\
\hline
\end{tabular}

Nồng độ Cystatin $\mathrm{C}$ huyết thanh ở nhóm ĐTĐ típ 2 lớn hơn có ý nghĩa so với nhóm chứng

Bảng 3.3. Mức lọc cầu thận ở các nhóm nghiên cứu

\begin{tabular}{|c|c|c|c|}
\hline GFR $\left(\mathrm{ml} /\right.$ phút $\left./ 1,73 \mathrm{~m}^{2}\right)$ & $\begin{array}{l}\text { Nhóm chứng } \\
\qquad(\mathrm{n}=115)\end{array}$ & $\begin{array}{c}\text { Nhóm ĐTÐT2 } \\
\quad(\mathbf{n}=137)\end{array}$ & $\mathbf{p}$ \\
\hline CKD-EPI creatinine & $\begin{array}{c}101,30 \\
(93,09-106,63)\end{array}$ & $\begin{array}{c}88,28 \\
(55,16-102,07)\end{array}$ & $<0,05$ \\
\hline CKD-EPI cystatin C & $\begin{array}{c}93,54 \\
(87,81-102,16)\end{array}$ & $\begin{array}{c}74,64 \\
(45,71-92,37)\end{array}$ & $<0,05$ \\
\hline \begin{tabular}{|l|} 
CKD-EPI \\
creatinine-cystatin C
\end{tabular} & $\begin{array}{c}97,56 \\
(92,10-104,40)\end{array}$ & $\begin{array}{c}79,60 \\
(49,06-96,59)\end{array}$ & $<0,05$ \\
\hline GFR theo xạ hình thận & - & $\begin{array}{c}87,38 \\
(60,29-109,04) \\
\end{array}$ & - \\
\hline
\end{tabular}

Mức lọc cầu thận ở nhóm ĐTĐT2 nhỏ hơn so với nhóm chứng, $\mathrm{p}<0,05$.

\subsection{Giá trị dự đoán giảm mức lọc cầu thận của Cystatin $\mathrm{C}$ huyết thanh}

Bảng 3.4. Tương quan giữa các công thức ước tính GFR với xạ hình thận ở nhóm ĐTĐT2

\begin{tabular}{|l|c|c|}
\hline \multirow{2}{*}{ GFR ước tính theo các công thức } & \multicolumn{2}{|c|}{ Xạ hình thận } \\
\cline { 2 - 3 } & $\mathrm{r}$ & $\mathrm{p}$ \\
\hline CKD-EPI creatinine & 0,754 & $<0,001$ \\
\hline CKD-EPI cystatin C & 0,816 & $<0,001$ \\
\hline $\begin{array}{l}\text { CKD-EPI } \\
\text { creatinine-cystatin C }\end{array}$ & 0,816 & $<0,001$ \\
\hline
\end{tabular}

GFR ước tính theo các công thức dựa vào cystatin $\mathrm{C}$ huyết thanh đơn độc hoặc phối hợp với creatinine tương quan chặt chẽ với xạ hình thận hơn so với công thức dựa vào creatinin huyết thanh, $\mathrm{p}<0,01$. 
Biểu đồ 3.1. Tương quan giữa GFR ước tính theo công thức CKD-EPI creatinine-cystatin $\mathrm{C}$ với xạ hình thận

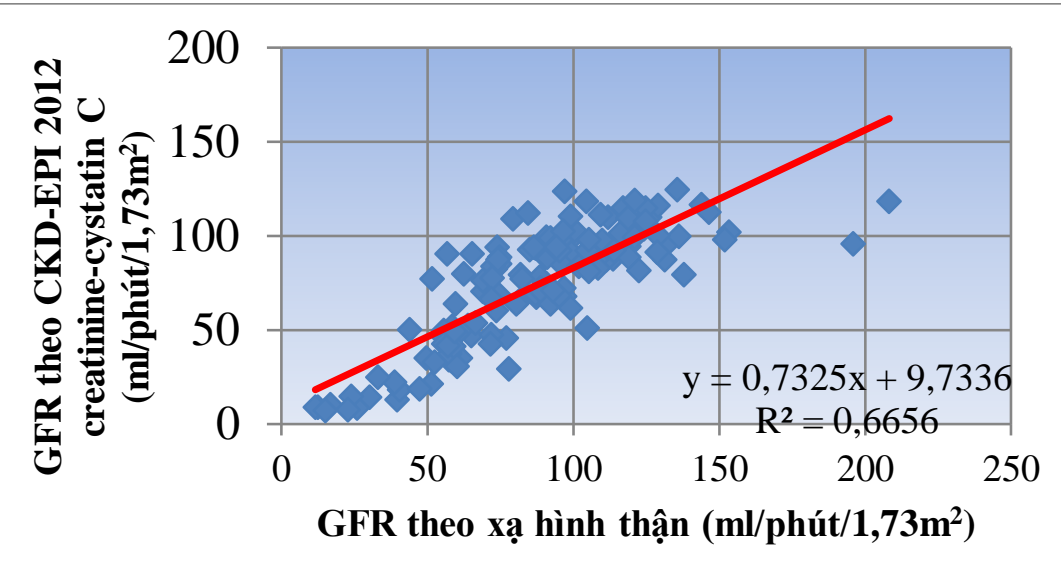

Bảng 3.5. Độ nhạy, độ đặc hiệu, AUC-ROC của cystatin $\mathrm{C}$ trong dự đoán giảm GFR $<60 \mathrm{ml} /$ phút $/ 1,73 \mathrm{~m}^{2}$ theo xạ hình thận

\begin{tabular}{|c|c|c|c|c|c|}
\hline \multirow{2}{*}{$\begin{array}{l}\text { Giá trị dự đoán } \\
\text { Chỉ số chức } \\
\text { năng thận }\end{array}$} & \multicolumn{5}{|c|}{$\begin{array}{c}\text { Bệnh thận mạn } \\
\text { GFR }<60 \mathrm{ml} / \mathrm{phút} / 1,73 \mathrm{~m}^{2}\end{array}$} \\
\hline & $\begin{array}{l}\text { Điểm } \\
\text { cắt }\end{array}$ & $\begin{array}{l}\text { Độ nhạy (\%) } \\
\text { (95\% CI) }\end{array}$ & $\begin{array}{c}\text { Độ đặc hiệu (\%) } \\
\text { (95\% CI) }\end{array}$ & $\begin{array}{l}\text { AUC-ROC } \\
(95 \% \mathrm{CI})\end{array}$ & $\mathrm{p}$ \\
\hline $\begin{array}{l}\text { Creatinine } \\
(\mu \mathrm{mol} / \mathrm{l})\end{array}$ & 103 & $\begin{array}{c}84,4 \\
(68,1-94,8)\end{array}$ & $\begin{array}{c}86,5 \\
(78,4-92,4)\end{array}$ & $\begin{array}{c}0,920 \\
(0,861-0,959)\end{array}$ & $<0,001$ \\
\hline $\begin{array}{l}\text { Cystatin C } \\
(\mathrm{mg} / \mathrm{L})\end{array}$ & 1,323 & $\begin{array}{c}93,94 \\
(79,7-99,1)\end{array}$ & $\begin{array}{c}87,5 \\
(79,6-93,2)\end{array}$ & $\begin{array}{c}0,936 \\
(0,882-0,971)\end{array}$ & $<0,001$ \\
\hline
\end{tabular}

Cystatin $\mathrm{C}$ huyết thanh có độ nhạy, độ đặc hiệu, diện tích dưới đường cong ROC cao hơn creatinine trong dự đoán giảm GFR $<60 \mathrm{ml} /$ phút $/ 1,73 \mathrm{~m}^{2}$.

Biểu đồ 3.2. Giá trị của cystatin $\mathrm{C}$ huyết thanh trong dự đoán giảmGFR < $60 \mathrm{ml} /$ phút $/ 1,73 \mathrm{~m}^{2}$ theo xạ hình thận

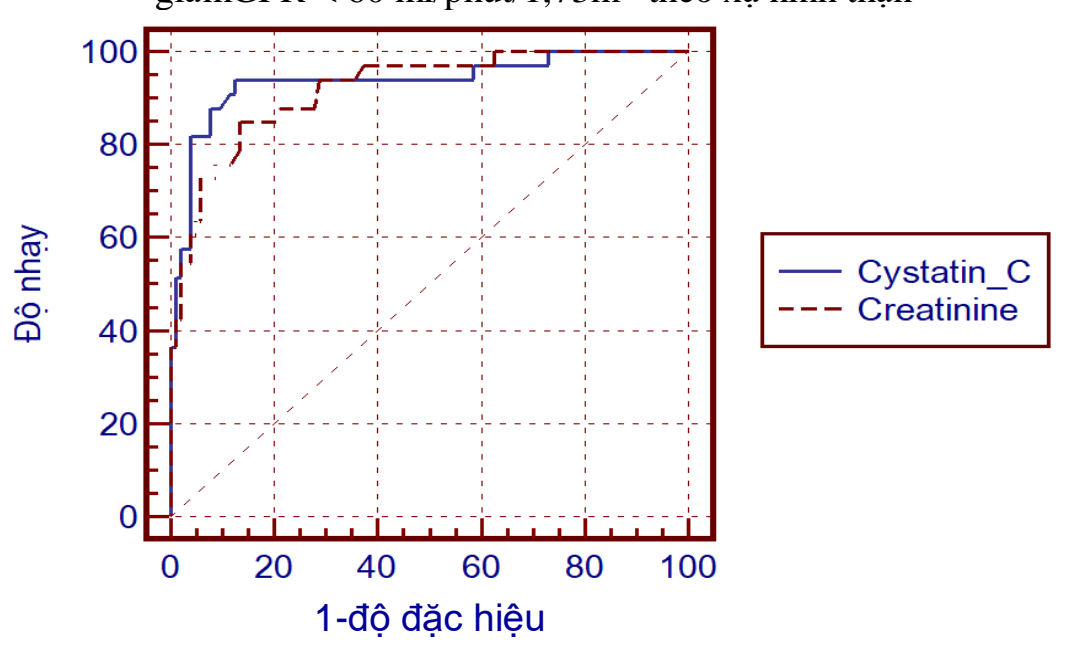

Bảng 3.6. Hồi quy binary logistic đa biến các YTNC dự đoán giảm GFR < $60 \mathrm{ml} /$ phút $/ 1,73 \mathrm{~m}^{2}$ ở nhóm ĐTĐT2 


\begin{tabular}{|l|c|c|c|c|c|}
\hline Thông số & B & Wald & OR & $\mathbf{9 5 \%}$ CI & p \\
\hline $\begin{array}{l}\text { Thời gian phát hiện } \\
\text { bệnh (năm) }\end{array}$ & $-0,036$ & 0,315 & 0,965 & $0,851-1,094$ & 0,575 \\
\hline Tăng huyết áp & 0,048 & 0,004 & 1,049 & $0,256-4,306$ & 0,947 \\
\hline HbA1c $(\%)$ & 0,059 & 0,137 & 1,061 & $0,776-1,451$ & 0,711 \\
\hline ACR $(\mathrm{mg} / \mathrm{mmol})$ & 0,001 & 0,001 & 1,000 & $0,992-1,008$ & 0,982 \\
\hline Creatinine $(\mu \mathrm{mol} / \mathrm{L})$ & 0,011 & 0,774 & 1,012 & $0,986-1,038$ & 0,379 \\
\hline Cystatin C $(\mathrm{mg} / \mathrm{L})$ & 3,841 & 7,773 & 46,583 & $3,129-693,43$ & $\mathbf{0 , 0 5}$ \\
\hline Constant & $-7,968$ & 13,445 & 0,001 & & $\mathbf{0 , 0 0 1}$ \\
\hline
\end{tabular}

Kết quả phân tích hồi quy đa biến binary logistic cho thấy chỉ có nồng độ cystatin $\mathrm{C}$ huyết thanh $(\mathrm{OR}=46,583 ; \mathrm{p}=0,005)$ là yếu tố nguy cơ độc lập duy nhất dự đoán giảm $\mathrm{GFR}<60$ $\mathrm{ml} / \mathrm{phút} / 1,73 \mathrm{~m}^{2}$. Creatinine huyết thanh không có khả năng dự đoán này.

Mô hình hồi quy binary logistic đa biến được xác định như sau:

Logistic GFR < $60 \mathrm{ml} /$ phút $/ 1,73 \mathrm{~m}^{2}$ ) = -7,968 +3,841 x cystatin C huyết thanh.

\section{BÀN LUẬN}

Trong thực hành lâm sàng, GFR được ước tính dựa trên sự đo lường các chất nội sinh trong máu, nồng độ creatinine huyết thanh là một dấu ấn sinh học đang được sử dụng rộng rãi ở hầu hết các phòng xét nghiệm như là một xét nghiệm đầu tiên trong đánh giá chức năng thận. Tuy nhiên, creatinine không đặc trưng cho GFR, vì nồng độ của nó bị ảnh hưởng bởi các yếu tố ngoài thận như tuổi tác, giới tính, chủng tộc, khối cơ, thuốc đang sử dụng, và chế độ ăn và một số bệnh lý đi kèm. Creatinine được lọc qua cầu thận $(90 \%)$, không được tái hấp thu tại ống thận nhưng được bài tiết thêm tại nơi này $(5-10 \%)[11],[12]$.

Gần đây đã có nhiều công trình nghiên cứu cho thấy rằng Cystatin $\mathrm{C}$ huyết thanh nổi lên như là một chỉ điểm sinh học có thể ứng dụng trong lâm sàng để đánh giá các rối loạn chức năng thận chính xác và sớm hơn các dấu ấn sinh học truyền thống trước đây như Creatinine máu [12], [17], [18].

Cystatin $\mathrm{C}$ là một protein trọng lượng phân tử thấp, được sản xuất bởi hầu hết các tế bào có nhân trong cơ thể với một tốc độ ổn định, nồng độ tuần hoàn không bị ảnh hưởng bởi những phản ứng pha cấp. Cystatin $\mathrm{C}$ được thải trừ duy nhất qua cầu thận, tái hấp thu và thoái hóa hoàn toàn tại tế bào ống thận, không được bài tiết bởi tế bào ống thận, không có đường vào lại tuần hoàn sau khi lọc bởi cầu thận. Cystatin $\mathrm{C}$ nổi lên là một dấu ấn sinh học được cho là có thể thay thế cho Creatinine để đánh giá chức năng thận [11], [12].

\subsection{Nồng độ Cystatin $\mathrm{C}$ huyết thanh ở các nhóm nghiên cứu}

Kết quả nghiên cứu của chúng tôi, nồng độ Cystatin $\mathrm{C}$ huyết thanhở nhóm ĐTĐT2 lớn hơn nhóm chứng có ý nghĩa thống kê.

Nghiên cứu của Phạm Quốc Toản và cộng sự (Hà Nội 2015), nồng độ Cystatin $\mathrm{C}$ trung bình ở người bình thường $(\mathrm{n}=30)$ là $0,78 \pm 0,13$ $\mathrm{mg} / \mathrm{l}$; bệnh nhân ĐTĐT2 không có tổn thương thận ( $\mathrm{n}=69$; albumin niệu âm tính và GFR $\geq$ $60 \mathrm{ml} / \mathrm{phút} / 1,73 \mathrm{~m}^{2}$ ) là $0,85 \pm 0,16 \mathrm{mg} / \mathrm{l}$; bệnh nhân ĐTĐT2 có tổn thương thận $(\mathrm{n}=136)$ là $01,51 \pm 0,78 \mathrm{mg} / 1, \mathrm{P}<0,05$ [4].

Nghiên cứu khác của Nguyễn Thị Lý và cs (Hà Nội 2012), nồng độ Cystatin C trung bình ở ĐTĐT2 albumin niệu âm tính $(\mathrm{n}=30)$ là $0,81 \pm 0,4 \mathrm{mg} / 1$; ĐТÐТ2 với Microalbumin niệu $(\mathrm{n}=30)$ là $1,59 \pm 0,66 \mathrm{mg} / \mathrm{l}$; ĐTĐT2 với Macroalbumin niệu $(\mathrm{n}=30)$ là $8,62 \pm 5,58 \mathrm{mg} / \mathrm{l}$, $\mathrm{p}<0,05[3]$.

Nghiên cứu của Richard P. Donahue et al (2007) trên 273 đối tượng bình thường không có tình trạng rối loạn glucose máu đói và rối loạn dung nạp glucose, nồng độ Cystatin $\mathrm{C}$ 
trung bình là $0,9 \pm 0,1 \mathrm{mg} / \mathrm{L}$. Nghiên cứu khác của Boo Wee Teo et al (2014) trên 2877 người châu Á, nồng độ Cystatin $\mathrm{C}$ trung bình là $0,98 \pm 0,27 \mathrm{mg} / \mathrm{L}$ [15].

Nghiên cứu của K. Sahakyan et al (2011), nồng độ Cystatin $\mathrm{C}$ ở người bình thường là 0,86 $\pm 0,19 \mathrm{mg} / \mathrm{L}(\mathrm{n}=2483)$, bệnh nhân ĐTĐ típ 2 mới phát hiện là $0,93 \pm 0,22 \mathrm{mg} / \mathrm{L}$ $(\mathrm{n}=275)$ [16].

Eun Hee Sim và cộng sự (2016), đã tiến hành nghiên cứu khảo sát mối liên quan giữa nồng độ cystatin $\mathrm{C}$ với $\mathrm{HbA1c}$. Đây là nghiên cứu lớn quy mô đầu tiên ở cộng động người châu Á trên 1559 người Hàn Quốc, nồng độ cystatin $\mathrm{C}$ ở nhóm glucose máu bình thường $(\mathrm{n}=1109)$ là $0,88 \pm 0,13 \mathrm{mg} / \mathrm{L}$; tiền ĐTĐ $(\mathrm{n}=339)$ là $0,91 \pm 0,14 \mathrm{mg} / \mathrm{L}$, ĐTĐT2 mới phát hiện $(\mathrm{n}=111)$ là $0,96 \pm 0,17 \mathrm{mg} / \mathrm{L}, \mathrm{p}<0,001$ [13].

Tăng nồng độ cystatin $\mathrm{C}$ huyết thanh trên các bệnh nhân rối loạn glucose máu là do liên quan với $\mathrm{CKD}$, giảm độ thanh thải của thận. Tăng nồng độ cystatin $\mathrm{C}$ có liên quan với tình trạng kháng insulin, tăng huyết áp, $\mathrm{HCCH}$, béo phì....[13]

4.2. Giá trị lâm sàng của Cystatin $C$ huyết thanh trong dự đoán mức lọc cầu thận

Công thức MDRD và CKD-EPI 2009 là các công thức ước tính GFR dựa vào creatinine được sử dụng phổ biến trong thực hành lâm sàng. Mặc dù các công thức này đơn giản, ít tốn kém, dễ thực hiện, nhưng các công thức trên không ước tính GFR một cách chính xác ở những đối tượng ĐTĐT2. Các công thức ước tính GFR dựa vào creatinine không phải là một công thức tốt trong dự đoán rối loạn chức năng thận giai đoạn sớm ở ĐTĐT2 khi so sánh với GFR ước tính dựa vào cystatin $\mathrm{C}$ huyết thanh [5], [7], [17], [18].

Kết quả nghiên cứu của chúng tôi, Cystatin $\mathrm{C}$ có độ nhạy, độ đặc hiệu, diện tích dưới đường cong ROC cao hơn creatinine trong chẩn đoán giảm GFR < $60 \mathrm{ml} /$ phút $/ 1,73 \mathrm{~m}^{2}$ ở ĐTĐT2 theo các công thức ước tính cũng như xạ hình thận. Diện tích dưới đường cong $\mathrm{ROC}$ của cystatin $\mathrm{C}$ trong chẩn đoán giảm GFR gần như cao trên mức 0,$9 ; \mathrm{p}<0,001$.

Nghiên cứu của Nguyễn Thị Lý và cộng sự (2012) trên bệnh nhân ĐTĐT2, với điểm cắt $\mathrm{GFR}<90 \mathrm{ml} /$ phút diện tích dưới đường cong ROC của cystatin $\mathrm{C}$ HT là 0,667 lớn hơn creatinine là $0,559(\mathrm{p}<0,05)$. Với điểm cắt GFR $<60 \mathrm{ml} /$ phút, diện tích dưới đường cong ROC của cystatin $\mathrm{C}$ là 0,893 lớn hơn creatinine là $0,826(\mathrm{p}<0,05)$ [3].

Nghiên cứu của Phạm Quốc Toản và cộng sự (2015) trên bệnh nhân ĐTĐT2 có tổn thương thận (albumin niệu và/hoặc giảm GFR $<60 \mathrm{ml} /$ phút $/ 1,73 \mathrm{~m}^{2}$ ), giá trị chẩn đoán tổn thương thận dựa vào cystatin $\mathrm{C}(\mathrm{ROC} 0,841$; $\mathrm{p}<0,05)$ lớn hơn creatinine (ROC 0,$778 ; \mathrm{p}<$ $0,05)[4]$.

Nghiên cứu khác của Nguyễn Thị Lệ và cộng sự (2007) trên bệnh nhân ĐTĐT2 cũng cho kết quả tương tự, nồng độ Cystatin C HT có độ nhạy, độ đặc hiệu trong chẩn đoán giảm GFR cao hơn so với creatinine [1].

Tuy nhiên các nghiên cứu trong nước ở bệnh nhân ĐTĐT2, GFR chỉ được ước tính qua các công thức hoặc độ thanh thải creatinine. Trong nghiên cứu của chúng tôi GFR được đo bằng xạ hình thận với hoạt chất DTPA, đây được xem là tiêu chuẩn vàng trong đánh giá GFR.

Gần đây nhất, một phân tích gộp của Amanda Veiga Cheuiche và cộng sự (2019) từ 23 nghiên cứu, bao gồm 7065 người tham gia, với 24 công thức ước tính GFR được phân tích trong khoảng dao động rộng của GFR. Hầu hết các nghiên cứu đều khẳng định rằng các công thức ước tính GFR chỉ dựa vào cystatin $\mathrm{C}$ hay phối hợp creatinine huyết thanh tương quan với GFR đo được bằng xạ hình thận trên bệnh nhân ĐTĐ [5].

Nghiên cứu của Frans J. Hoek và cộng sự (Hà Lan) trên 93 đối tượng nghi ngờ CKD (trong đó ĐTĐT2 là 30 bệnh nhân), độ nhạy và độ đặc hiệu của cystatin $\mathrm{C}$ trong chẩn đoán giảm GFR tại điểm cắt $90 \mathrm{ml} / \mathrm{phút} / 1,73 \mathrm{~m}^{2}$ là $76,9 \% ; 89,1 \%$; diện tích dưới đường cong ROC là 0,932 (ROC của creatinine là 0,877 ). Độ nhạy, độ đặc hiệu của cystatin $\mathrm{C}$ trong chẩn đoán giảm GFR tại điểm cắt 60 
ml/phút/1,73 m² là 97,7\%; 67\%; diện tích dưới đường cong ROC là 0,963 (ROC của creatinine là 0,924). Nghiên cứu khác của Michele Mussap và cộng sự (Ý 2002) trên 52 bệnh nhân ĐTĐT2, độ nhạy và độ đặc hiệu của cystatin $\mathrm{C}$ trong chẩn đoán giảm GFR tại điểm cắt $80 \mathrm{ml} /$ phút $/ 1,73 \mathrm{~m}^{2}$ là $97 \%, 81 \%$, so với creatinine là $62 \%, 89 \%$ [7].

Nghiên cứu của Yun Kyung Jeon và cộng sự (Hàn Quốc 2011) trên 332 bệnh nhân ĐTĐT2 cũng cho thấy cystatin $\mathrm{C}$ có độ nhạy, độ đặc hiệu cao trong chẩn đoán giảm GFR. Với điểm cắt cystatin $\mathrm{C}$ là $1,06 \mathrm{mg} / \mathrm{L}$ trong chẩn đoán giảm GFR $<60 \mathrm{ml} /$ phút $/ 1,73 \mathrm{~m}^{2}$ có độ nhạy $81 \%$, độ đặc hiệu $87,1 \%$, diện tích dưới đường cong ROC là $0,906(95 \% \mathrm{CI}$ : 0,865-0,947) [18]. Nghiên cứu khác của Zhang và cộng sự ở bệnh nhân ĐTĐT2 cũng cho thấy rằng giá trị chẩn đoán giảm $\mathrm{GFR}<$ $90 \mathrm{ml} /$ phút $/ 1,73 \mathrm{~m}^{2}$ của cystatin $\mathrm{C}$ với diện tích dưới đường cong ROC là 0,915 cao hơn so với creatinine $0,902(\mathrm{p}<0,01)$ [18].

Nghiên cứu khác của Suzuki và cộng sự (Nhật 2012) ở 352 bệnh nhân ĐTĐT2 cho thấy cystatin $\mathrm{C}$ có độ nhạy, độ đặc hiệu, diện tích dưới đường cong ROC cao hơn creatinine trong chẩn đoán bệnh thận mạn ở tất cả các giai đoạn và các mức độ bài xuất albumin niệu khác nhau, đặc biệt trong các giai đoạn sớm I, II của bệnh nhân CKD [17].

Như vậy, hầu hết các nghiên cứu đều cho thấy rằng cystatin $\mathrm{C}$ có giá trị chẩn đoán giảm GFR hơn creatinine với độ nhạy, độ đặc hiệu và diện tích dưới đường cong $\mathrm{ROC}$ cao hơn.

Trong nghiên cứu của chúng tôi, phân tích hồi quy đa biến logistic các yếu tố ảnh hưởng đến giảm GFR $<60 \mathrm{ml} /$ phút $/ 1,73 \mathrm{~m}^{2}$ (hay CKD) cho thấy chỉ có cystatin $\mathrm{C}$ là yếu tố nguy cơ độc lập duy nhất có khả năng dự đoán bệnh thận ĐTĐ hay CKD ở nhóm ĐTĐТ2 (OR 46,583; $\mathrm{p}<0,05)$, còn creatinine huyết thanh thì không.

Nghiên cứu của Phạm Quốc Toản và cộng sự (2015) trên 205 bệnh nhân ĐTĐ, cũng cho thấy tăng nồng độ cystatin $\mathrm{C}$ là yếu tố nguy cơ độc lập ảnh hưởng đến tổn thương thận ở bệnh nhân ĐTĐ (OR 66,55; CI 95\%: 9,97$444,3 ; \mathrm{p}<0,05)$, trong khi đó creatinine không có liên quan, $\mathrm{p}<0,05$ [4]. Nghiên cứu của Yun Kyung Jeon và cộng sự (2010) cho thấy cystatin $\mathrm{C}$ là yếu tố độc lập dự báo giảm GFR < $60 \mathrm{ml} /$ phút $/ 1,73 \mathrm{~m}^{2}$ ở bệnh nhân ĐTĐT2 với bài xuất albumin niệu bình thường (OR: 14,6; CI 95\%: 4,79-44,52, p < $0,001)$ [18].

Tóm lại, kết quả nghiên cứu của chúng tôi cũng như kết quả của các tác giả khác đều cho thấy giá trị của cystatin $\mathrm{C}$ cũng như các công thức ước tính GFR dựa vào cystatin $\mathrm{C}$ có thể dự báo chính xác giảm GFR hơn so với creatinine. Nồng độ cystatin $\mathrm{C}$ biến đổi sớm trước khi có sự xuất hiện của albumin niệu, ngay cả khi creatinine huyết thanh và GFR dựa vào creatinine còn trong giới hạn bình thường.

\section{KẾT LUẬN}

- Nồng độ Cystatin C huyết thanh ở ĐTĐ típ 2 cao hơn có ý nghĩa so với đối tượng có glucose máu và GFR bình thường, $\mathrm{p}<0,001$.

- Có mối tương quan thuận giữa GFR ước tính dựa vào Cystatin $C$ và GFR xạ hình thận.

Cystatin $\mathrm{C}$ có độ nhạy và độ đặc hiệu cao trong phát hiện giảm GFR $<60$ $\mathrm{ml} /$ phút $/ 1,73 \mathrm{~m}^{2}$ so với Creatinine huyết thanh.

Cystatin $\mathrm{C}$ là yếu tố nguy cơ độc lập dự đoán giảm mức lọc cầu thận.

\section{TÀI LIỆU THAM KHẢO}

1. Nguyễn Thị Lệ (2007), Đánh giá độ lọc cầu thận bằng phuoong pháp đo độ thanh lọc Creatinin 24 giò̀ và Cystatin C huyết thanh, Luận án tiến sĩ Y học, Đại học Y Dược Hồ Chí Minh.

2. Hội Nội Tiết và Đái tháo đường Việt Nam (2018), Khuyến cáo về chẩn đoán và điều trị bệnh đái tháo đường, Nhà xuất bản Y học, tr. 9-40.

3. Nguyễn Thị Lý, Trần Thị Chi Mai (2012), "Nồng độ Cystatin $\mathrm{C}$ máu và chức năng thận ở bệnh nhân đái tháo đường típ 2", TCNCYH, tr. 17-23.

4. Phạm Quốc Toản (2015), Nồng độ Cystatin C huyết thanh, nước tiểu ở bệnh nhân đái tháo đường typ 2 có tổn thương thận, Luận án tiến sĩ Y học, Bộ Giáo dục 
Đào tạo, Học viện Quân y.

5. Amanda Veiga Cheuiche, Marina Queiroz, Andre Luis Ferreira Azeredo da Silva et al. (2019), "Performance of Cystatin C-Based equations for estimation of Glomerular Filtration Rate in Diabetes patients: A prisma Compliant systematic Review and Meta-Analysis", Scientific reports, 9: 1418, pp. 1-10.

6. American Diabetes Association (2018), "Standards of medical care in Diabetes2018", Diabetes Care, vol. 41, pp. S13S105.

7. Frans J. Hoek, Frits A. W. Kemperman, Raymond T. Krediet (2003), "Comparison between Cystatin C, plasma creatinine and Cockcroft Gault formula for estimation of glomerular filtration rate", Nephrol Dial Transplant, 18, pp. 2024-2031.

8. International Diabetes Federation (2017), "The global picture", IDF Diabetes Atlas 8th Edition, pp. 40 - 63.

9. KDIGO (2012), "KDIGO 2012 clinical practice guideline for the evaluation and management of chronic kidney disease", Kidney International Supplements, 3(1), pp. 19-62.

10. Andrew S. Levey, Lesley A. Inker (2017), "Assessment of Glomerular Filtration Rate in Health and Disease: A State of the Art Review", Clinical Pharmacology and therapeutics, vol. 102, no. 3, pp. 405-419.

11. Leskey A. Inker, Christopher H. Schmid, Hocine Tighouart (2012), "Estimating Glomerular Filtration Rate from serum Creatinine and Cystatin C", $N$ Engl J Med, 367(1), pp. 20-29.
12. Lesley A. Stevens, Josef Coresh, Harold I. Feldman et al. (2008), "Estimating GFR using Serum Cystatin C Alone and in Combination with Serum Creatinine: A Pooled Analysis of 3418 Individuals with CKD”, Am J Kidney Dis, 51(3), pp. 395406.

13. Eun Hee Sim, Hye Won Lee, Hyun Ju Choi et al. (2016), "The Association of Serum Cystatin C with Glycosylated Hemoglobin in Korean Adults", Diabetes Metab J, 40, pp. 62-69.

14. National Kidney Foundation (2012), "KDOQI Clinical practice guideline for diabetes and chronic kidney disease: 2012 update", Am J Kidney Dis, 60(5), pp. 850-886.

15. Richard P. Donahue, Saverio Stranges, Karol Rejman et al. (2007), "Elevated Cystatin C Concentration and Progression to Pre-Diabetes", Diabetes Care, 30, pp. 1724-1729.

16. Sahakyan K., Lee K.E., Shankar A. et al. (2007), "Serum cystatin C and the incidence of type 2 diabetes mellitus", Diabetologia, 54(6), pp. 1335-1340.

17. Suzuki Y., Matsushita K., Seimiya M. et al. (2012), "Serum cystatin C as a marker for early detection of chronic kidney disease and grade 2 nephropathy in Japanese patients with type 2 diabetes", Clin Chem Lab Med, 50(10), pp. 18331839.

18. Yun Kyung Jeon, Mi Ra Kim, Jung Eun Hub et al. (2011), "Cystatin C as an early biomarker of nephropathy in patients with type 2 diabetes", J Korean Med Sci, 26, pp. 258-263. 